\title{
Labyrinthe
}

31 | 2008 (3)

Revues modes d'emploi

\section{Généralistes, spécialistes et vulgarisateurs}

\section{(2) OpenEdition \\ 12 Journals}

Édition électronique

URL : http://journals.openedition.org/labyrinthe/3869

DOI : $10.4000 /$ labyrinthe.3869

ISSN : 1950-6031

Éditeur

Hermann

Édition imprimée

Date de publication : 15 octobre 2008

ISBN : 978-2-9526131-8-7

Référence électronique

"Généralistes, spécialistes et vulgarisateurs », Labyrinthe [En ligne], 31 | 2008 (3), mis en ligne le 08 novembre 2008, consulté le 07 mai 2019. URL : http://journals.openedition.org/labyrinthe/3869; DOI : 10.4000/labyrinthe.3869

Ce document a été généré automatiquement le 7 mai 2019.

Propriété intellectuelle 
Généralistes, spécialistes et vulgarisateurs 